\title{
APPROACHES TO ASSESSMENT OF RELIEF-FORMING PROCESSES UNDER CONDITIONS OF GLOBAL WARMING (WITH REFERENCE TO NORTHERN EURASIA WITHIN THE BOUNDARIES OF THE FORMER USSR)
}

\author{
ANDREY A. VELICHKO, IRINA I. SPASSKAYA \\ Laboratory of Evolutionary Geography, Institute of Geography, Russian Academy of Sciences, \\ Staromonetny per. 29, Moscow 119017, Russia; \\ E-mail: paleo_igras@mail.ru
}

\begin{abstract}
Palaeoclimatic characteristics based on paleogeographic reconstructions for the optimums of the Holocene and the last interglacial appear to be close in estimated range of global warming to those expected in the current century according to IPCC (scenario A1B). Reconstructions of the state of environmental components in Northern Eurasia under given seasonal and annual temperature and precipitations allowed developing scenarios of expected changes in ecosystems within individual landscape zones. Regions of most probable appearance of instability in ecosystems are mostly confined to northern lowlands (permafrost degradation), plains in the southern East European Plain (accelerated erosion) and southern mountains (mudflows, landslides, etc.).
\end{abstract}

Key words: palaeoclimates, global warming, ecosystems, prognosis, relief-forming processes, Northern Eurasia

The problem of trends in evolution of landscapes has been the focus of attention for decades and it became particularly acute due to the global warming. One of the most common approaches is to use palaeogeographic scenarios as models of the future state of environments. Most often discussed are prognoses (or to be more precise, projections) of the state of environmental components under conditions of the global warming by $\sim 1^{\circ}$ and by $2^{\circ} \mathrm{C}$ (Parry et al., 2007). Such a situation is considered to be most probable in the current century due to the man-induced warming. It is extremely important to know whether the existing relief would keep its stability, what hazardous relief-forming processes may be activated in the near future and where they are most likely to occur.

It may be noted that scenarios of geosystem behaviour are much more difficult to develop than climatic scenarios. The difficulties are predetermined by incompleteness of our knowledge of mechanisms controlling the geosystem functioning, with their intricate interaction of various biohydrogeochemical cycles.

A new class of problems arises when we consider the geosystem response to short-term and abrupt changes in hydrothermal regime. There are some properties of geosystems which must be taken into account when dealing with the predicted changes in climate. First to be mentioned 
is "inertia" or lag in response (a time lag between the beginning of climate change and the geosystem readjustment). When we deal with complex systems it is quite impossible to understand the changes in the entire system at once. Every component of the geosystem takes its own time to transform and adjust itself to the newly established climatic regime. The difference in adjustment of various geosystem components - their characteristic time - varies over wide limits, from 1-2 years for sea ice and a little longer (tens of years) for active layer thickness in permafrost, to tens and a few hundreds of years for noticeable changes in vegetation zone boundaries; still more inert seem to be soil and landform assemblages (Fig. 1). This accounts for heterogeneity of landscape sphere, i.e. the coexistence of elements of different age and the presence of a number of inherited elements in modern landscape; some of them may persist under the present hydrothermal regime, but their destruction (for example, in case of man-induced changes in landscapes) would be irreversible (Velichko. 1989, 1991).
Moreover, even if we take into account a single component of the geosystem, its own constituents form a noticeably diversified spectrum of "characteristic times". This may be shown by the example of landform assemblage. Considering the relief as a whole, its transformation would take hundreds of years. Major topographic units (morphostructures) will be hardly affected at all by the climatic change. But even exogenous processes, such as fluvial erosion and slope processes would form a large family of characteristic times under conditions of changing precipitation regimes: from one year (earthflows, landslides or small erosional rills) to hundreds of years and millennia (formation of fluvial terraces in valleys).

Investigations carried out for many years in the Laboratory of Evolutionary Geography (Institute of Geography, Russian Academy of Sciences) made it possible to develop palaeoclimatic and palaeoenvironmental reconstructions for extreme moments of the last natural macro-cycle (about 140 thousand years) (Velichko, 2002, 2009, 2010). In the course of our work, palaeoclimatic maps

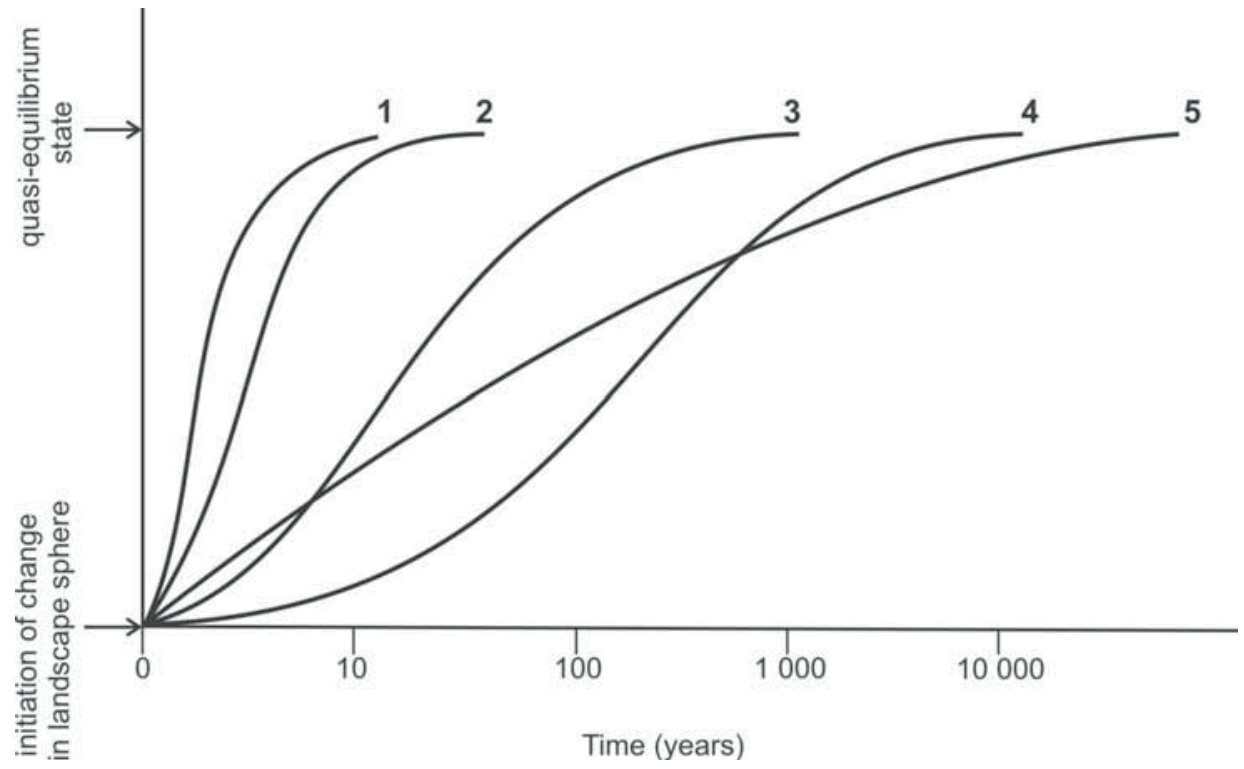

Figure 1. Characteristic times required by different components of landscapes for coming into the quasi-equilibrium state after sharp climatic change.

1 -sea ice, 2 - active layer of permafrost, 3 - vegetation, 4 - soils, 5 - relief (topography). 
have been compiled showing precipitation (mean annual and seasonal) and temperatures in Northern Eurasia at the time intervals when global temperature was higher than at present by $0.6-0.8^{\circ} \mathrm{C}$ (the Holocene optimum) and by $1.6-1.8^{\circ} \mathrm{C}$ (the last Late Pleistocene interglacial) (Fig. 2). It should be noted that the named values based on palaeoreconstructions using palaeobiological, palaeocryological and other methods appeared close enough to the estimates by IPCC (Parry et al., 2007).

The above-named time intervals (the Holocene and the Late Pleistocene interglacial optimums) have been chosen as a basis for development of our prognostic scenarios as the values of mean global temperatures calculated for those intervals are close to the temperatures to be expected in the first few decades (an analog of the Holocene optimum) and at the middle of the century (analog of the last interglacial). In both cases, a greater increase in winter and summer temperatures is found in high latitudes, especially in the north of Central Siberia (by $10-12^{\circ}$ in winter and $\sim 8^{\circ} \mathrm{C}$ in summer). Positive deviations in winter temperatures are expected in the central regions of the East European Plain $\left(8-10^{\circ} \mathrm{C}\right)$, and slightly less - in Siberia north of $50^{\circ} \mathrm{N}$. The summer temperatures, however, hardly exceeded the modern ones and became negligible in the southern part of the temperate belt. As for annual sum of precipitation, at the last interglacial time, it was somewhat greater in all latitudes, though there existed considerable regional differences. In the Arctic the greatest increase - over $200 \mathrm{~mm}$ - is registered in high latitude coastal regions of Siberia (Yamal, Gydan, and Taimyr peninsulas). Similar increase took place in the southwest of the East European Plain (200 to $300 \mathrm{~mm}$ north of the Black Sea). The values of positive deviations decreased to $100 \mathrm{~mm}$ and less over most of the mid-latitude belt and were close to that value even in the arid regions of southern Siberia and Kazakhstan (Velichko et al., 1991; Frenzel et al., 1992; Velichko, 2010). In our opinion, the palaeoclimatic reconstructions developed for the last interglacial optimum may well be used as scenarios of the future (within a century) climates.

As for reconstructed components of palaeoenvironments, it is more complicated. The palaeogeographic map-reconstructions obtained for the named time intervals are to be considered as equilibrium models, when geosystems had time enough to get into equilibrium with the changed climate. Such models are of a considerable interest as they provide the most reliable source of data on the transformation of systems affected by the warming of the given level and on the trends of this transformation. It is more important, however, to consider non-equilibrium models where the mechanism of interaction between the landscape-forming constituents was disturbed due to differences in characteristic time of individual components.

An analysis of the geosystem response to extremely sharp changes in temperature and humidity within a span of several decades presents a new trend in prognostic researches in geography. The first attempts revealed some previously unknown properties of natural territorial complexes that are necessary to take into consideration in order to estimate correctly the effect of foregoing climatic changes. These include, first of all, the above mentioned time response lag (inertia) and difference of time intervals needed for various elements of the geosystem for adjustment to changed climatic situation.

On the whole, we may state that a noticeable shift of the zonal boundaries is hardly possible over a period of a few decades (Zelikson et al., 2010), so an assortment of geomorphic processes known to be active in every zone would persist in the future over a considered time interval (a few decades - a century). It should be kept in mind, however, that some geomorphic processes, including potentially hazardous ones, may become active in case some other environmental characteristics undergo change - for example, in case of the natural vegetation destroyed by human interference. This aspect is noteworthy when the human impact on environments is analysed. 

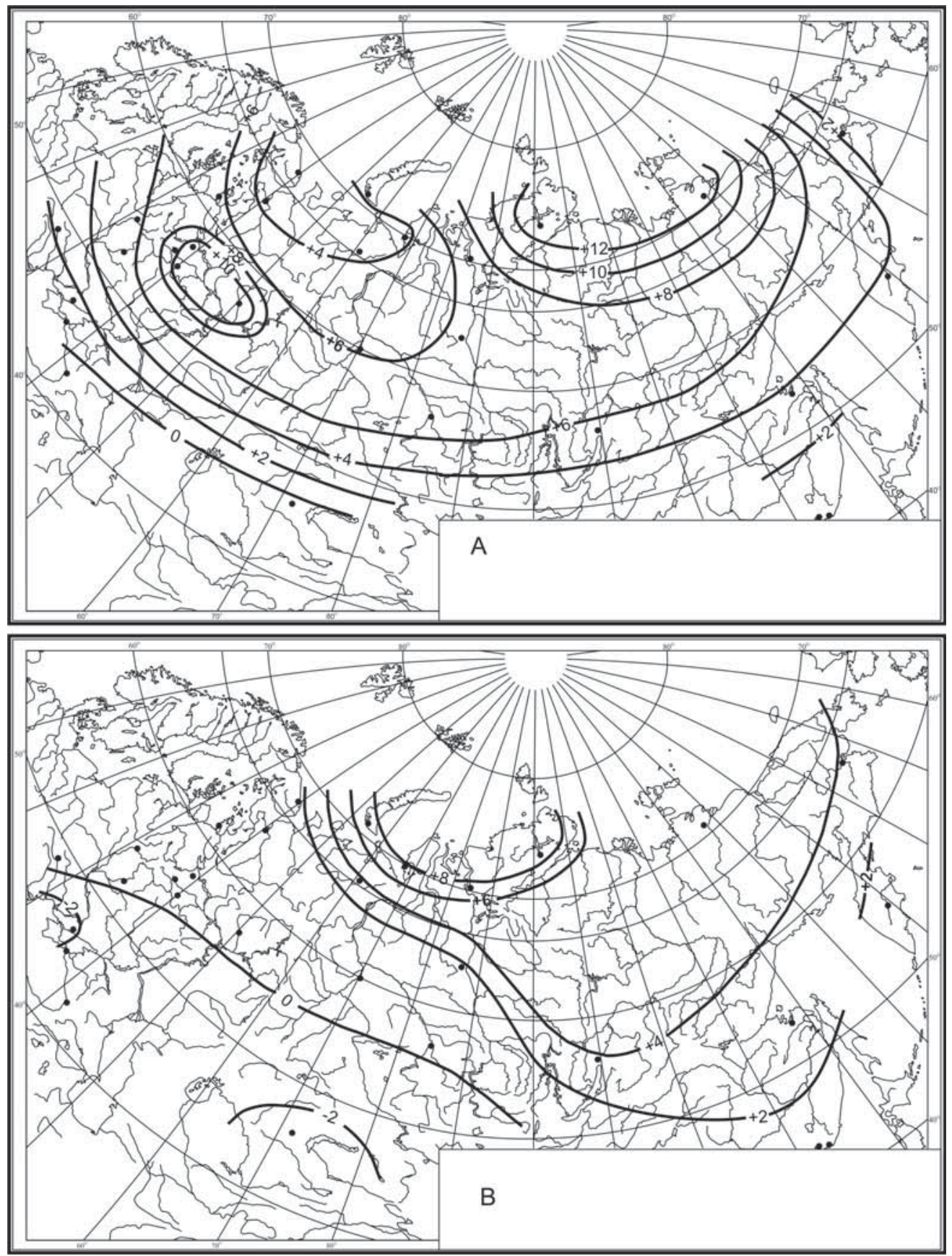

Figure 2. Mean temperatures of January (A) and July (B) at the climatic optimum of the last interglacial (Mikulino - Eemian) shown as deviations from the present-day temperatures. Dots indicate sections used in the palaeoclimatic reconstructions. 
Of special interest in this context is the palaeogeographic aspect of this problem. The point is that those potential hazards are to some extent inherited from the past states of the landscape. For example, in the central part of the East European Plain there is a vast zone of sandy deposits, mostly related to the Pleistocene fluvioglacial deposition and to large river terraces. At present, they are mostly fixed with vegetation, but in case of deforestation the aeolian processes would be activated and fields of wind-blown sands would develop (as occurred repeatedly at local scale during the Late Glacial and the Holocene). Another "inherited" constituent is loess cover widely spread in the south of the East European Plain. Many undesirable processes typical for loess areas (soil subsidence, landslides, piping, accelerated soil erosion) are due to their lithological properties, which developed under conditions of glacial epochs and are a product of cryo-arid climate (Velichko, 2002).

Below, we will consider some environmental changes which may be expected within the main natural zones of Northern Eurasia under the predicted changes of climate.

Arctic regions. According to models based on palaeoclimatic reconstructions (Velichko, 2010), the positive deviations of temperatures are well pronounced in high latitudes. By the middle of the $21^{\text {st }}$ century, positive deviations of summer temperatures in the European sector of the Arctic are expected to be $2-3^{\circ} \mathrm{C}$ above the present values and to increase in Siberia by $6-8^{\circ} \mathrm{C}$ (see Fig. 2). Even more conspicuous are positive deviations in winter, which may be in excess of $10^{\circ} \mathrm{C}$ in northern Siberia. Such a warming would increase duration of the ice-free ocean and therefore the navigation period. It should be also noted that the longer period of ice-free ocean and earlier breaking of fast ice would increase considerably the rate of marine erosion on coasts composed of frozen loose sediments. The predicted rise of the World Ocean level would also contribute to the coastal erosion.

In spite of noticeable growth in precipitation, the Arctic glaciers are expected to shrink faster (Kotlyakov et al., 1991). According to preliminary calculations, the deficit of precipitation needed for sustaining stationary state of glaciers would increase at least twofold on the Novaya Zemlya and Novosibirskiye Islands and by 4 times on Severnaya Zemlya. This would result in a considerable reduction of glaciated area (by 60 to $80 \%$ ) (Davidovich et al., 2010). The mitigation of climate would facilitate the arctic desert replacement with tundra.

Tundra zone. By the middle of the $21^{\text {st }}$ century, both summer and winter temperature are expected to grow, especially between the Polar Urals and the Lena River (by $8^{\circ}$ to $12^{\circ} \mathrm{C}$ ). Both west and east of these regions the temperature growth would be somewhat smaller (by about $4^{\circ} \mathrm{C}$ and less). An increase in annual rainfall by $\sim 100 \mathrm{~mm}$ would not affect seriously the hydrothermal conditions. Against the background of warming, the wetland areas may be even reduced. A decay of permafrost, and first of all a noticeable increase in the active layer thickness would lead to intensified solifluction, which would affect adversely the stability of constructions and functioning of oil and gas pipelines. Frozen ground with high ice content would be especially susceptible to thermokarst and thermal erosion; the latter would be most active on coasts of the Siberian lowlands. A special kind of thermal erosion develops on valley sides in the tundra zone due to melting of ice wedges; sometimes this leads to activation gully erosion.

Temperate forest zone. No considerable changes in hydrothermal regime are expected in this zone. In the first decades of the century in Eastern Europe both winter and summer temperatures may rise by $3-4^{\circ}$ (and even less at the southern margin of the forest zone), along with slightly higher rainfall (by $\sim 50 \mathrm{~mm}$ ). It is noteworthy that at the Holocene optimum, when the mean global temperature was about $0.6-0.8^{\circ}$ above the today's, the central regions of the East European Plain were marked by slightly lower rainfall amount than at present (by 25 to 50 $\mathrm{mm}$ ). If that is true for the future climates, one could expect a noticeable reduction of 
wetland area. Of special interest is the state of geosystems in the central regions of the European Russia, and especially southern part of them, which are heavily cultivated and overexploited. Here, an increase of drought frequency is quite probable and may result in soil fissuring and wind erosion; dust storms may become frequent and highly destructive. Later on, however, since the middle of the century, when the mean global temperature would be close to that of the last interglacial $\left(1.6-1.8^{\circ} \mathrm{C}\right)$ the precipitation would exceed its today's level all over the forest zone. At the same time, the growth of winter and summer temperature will be higher than at present (see Fig. 2).

An increase in precipitation may result in aggravating of flood hazard. Catastrophic floods in European Russia occur mostly in spring and are related to snow melting. More abundant snowfalls, and therefore a greater amount of water stored in snow, and higher temperature in spring may induce highly destructive snowmelt floods (Starkel, 2002). Moreover, the higher soil humidity might activate mass wasting processes on valley slopes, in particular slumping, earthflows, creep, etc.

The catastrophic floods are less likely in West Siberia, where the terrain is mostly flat and abounds in wetlands. In Central and Eastern Siberia, however, the flood hazard is quite real. According to estimates by Mokhov et al. (2002) on the basis of ECHAM4/ OPYC3 and HadCM3 models, precipitation in the Lena and Yenisei drainage basins would increase by the end of the century by $18-16 \%$ and $12-10 \%$, respectively. Accordingly, the yearly runoff would also grow, and as a result, probability of high floods on rivers belonging to the Lena and Yenisei basins would be essentially higher. A contributing factor would be ice jams on the rivers flowing northward; the occurrence of the ice jams would be all the more probable because of the earlier beginning of the snowmelt flood in spring under conditions of general warming.

In Siberia east of the Yenisei River, the warming would be much more noticeable.
The January temperatures, for example, would rise by $6-8^{\circ} \mathrm{C}$ in central Yakutia and by $10^{\circ}$ in its northern part. Such a warming would result first of all in increase of the thickness of seasonally thawing (active) layer by 40-60 $\mathrm{cm}$. Overwetting of soil due to ground ice melting might result in activation of solifluction processes.

The predicted rise in temperatures would hardly affect the zonal boundaries. The shift of either northern or southern forest limits would take at least several hundreds of years, so the changes in vegetation would amount to restructuring within tree communities, shifting of some tree ranges northward by a few kilometers, etc. It is possible, however, that riverine forests may penetrate farther north along river valleys. The expected increase in rainfall (by $100 \mathrm{~mm}$ ) would not result in perceptible growth of soil erosion unless the natural vegetation is seriously damaged. On the whole, the temperate forest zone may be considered the most stable and least vulnerable under the predicted climate conditions.

Semiarid and arid geosystems. Somewhat different are expected changes in the steppe geosystems in the south of the East European Plain and northern Kazakhstan. Taking the palaeoclimatic models as analogues of the future, we may expect some rise in winter temperatures - by $1-3^{\circ} \mathrm{C}$ in the first decades of the $21^{\text {st }}$ century and up to $2-5^{\circ} \mathrm{C}$ in the middle of it. No rise of summer temperatures is expected; it is not improbable that they will be a little lower than at present (presumably by $1-2^{\circ}$ at the middle of the century). Against such a temperature background, annual rainfall is expected to increase as much as $300-200 \mathrm{~mm}$ in the European steppes and about $100 \mathrm{~m}$ in the north of Kazakhstan. In all probability, this would result in the increased proportion of mesophytes in natural coenoses as well as in higher-yielding crops on cultivated lands.

The predicted rise of rainfall is favourable for a development of a thicker grass cover in the natural ecosystems that would protect the surface from erosion. However, the erosion hazard strongly depends on 
land use and on the arable land percentage in particular, and as the greatest portion of the territory has been cultivated for a long time and its natural vegetation is completely destroyed, negative consequences of the predicted changes in precipitation are most likely. This is particularly true of the southwest of the East European Plain, where the most considerable increase in precipitation (by 200 to $300 \mathrm{~mm}$ ) is to be expected. High erodibility of soils, especially those on loess, in steppes and forest-steppe is indicated by values of measured solid runoff, which in small drainage basins is about $70 \mathrm{t} / \mathrm{km}^{2}$ per year. It has also been noted (Dedkov and Mozzherin, 1984) that the more intense is land use, the more dependable is soil erosion on the precipitation. Under the present-day conditions, the predicted increase in rainfall would result in a considerable increase in soil loss from arable slopes, probably by a factor of 2 or more (on loess in particular), due to more active sheet and rill wash, piping, gully erosion, etc. The eroded matter is partly deposited at the foot of slopes or on floodplains where the soil fertility may be lessened by alluviation. It also results in a rapid silting of water storage reservoirs on small rivers. The area of positive deviations of rainfall (more than $100 \mathrm{~mm}$ ) extends eastwards, including the Caspian Lowland, south of West Siberia and northern Kazakhstan. A considerable part of these areas is used as pasture, so the effect on soil erosion may be negligible.

Mountains. Mountains bordering on the south the plains of Northern Eurasia, such as the Caucasus, Pamir and Tien-Shan, Sayans, etc., deserve a special attention. An increase in cyclonic activity and, consequently, in rainfall would result in activating a complex of hazardous, locally catastrophic processes. In the Caucasus, for example, abundant rains would result in increased frequency of mudflows, landslides, avalanches; fluvial erosion would intensify in valleys and on slopes. In the Central Asia mountains, where the vegetation is more scarce, the response of geomorphic processes to increased rainfall would be no less intense. In addition to those noted above, there will be intensified growth of proluvial aprons and alluvial fans that may reduce the area of cultivable land in valleys. One can easily visualize the gravity of the changes in the mentioned processes for agriculture, as well as for road construction and maintenance and hydroelectric development in mountains.

Of special interest is the state of alpine glaciation (Kotlyakov, 2006). As far as the Caucasus is concerned, some preliminary calculations (Velichko, 1992) showed that, in spite of the negative mass balance of glaciers and increasing rate of thawing, the growth of precipitation would reduce the mass deficit and the glacier retreat would slow down. Nevertheless, it is expected that the process of glaciation decay would continue (due to the rising temperature) and glaciated area of the Great Caucasus would be reduced by $30 \%$ within the a few decades (Semenov, 2008). Some dangerous processes may occur in mountains as a result of deglaciation. This process is usually accompanied by debris melting out of ice, an increase in solid runoff of the mountain streams, and quite often - by mudflows with great volumes of debris moved to large valleys or in the forelands (Lurye et al., 2005).

Similar estimates performed for Pamir (Velichko and Lebedeva, 1974) suggested that the increase in rainfall would probably result in an advance of glaciers and growth of river discharge (including Syrdarya and Amydarya), which, in turn, would produce a positive effect on the Aral Sea.

As for closed water basins in the present-day arid belt, it may be said with confidence that a general increase in precipitation along with a somewhat lower summer temperature would have a positive effect on their water budget. As follows from the calculations of the Caspian Sea water budget, the sea level is likely to rise due to decrease in total evaporation from the sea surface, first by at least $3 \%$ and then by $6 \%$.

Presenting this quick overview of possible changes in the state of geosystems in response to the anthropogenic warming, the authors would like to stress a necessity 


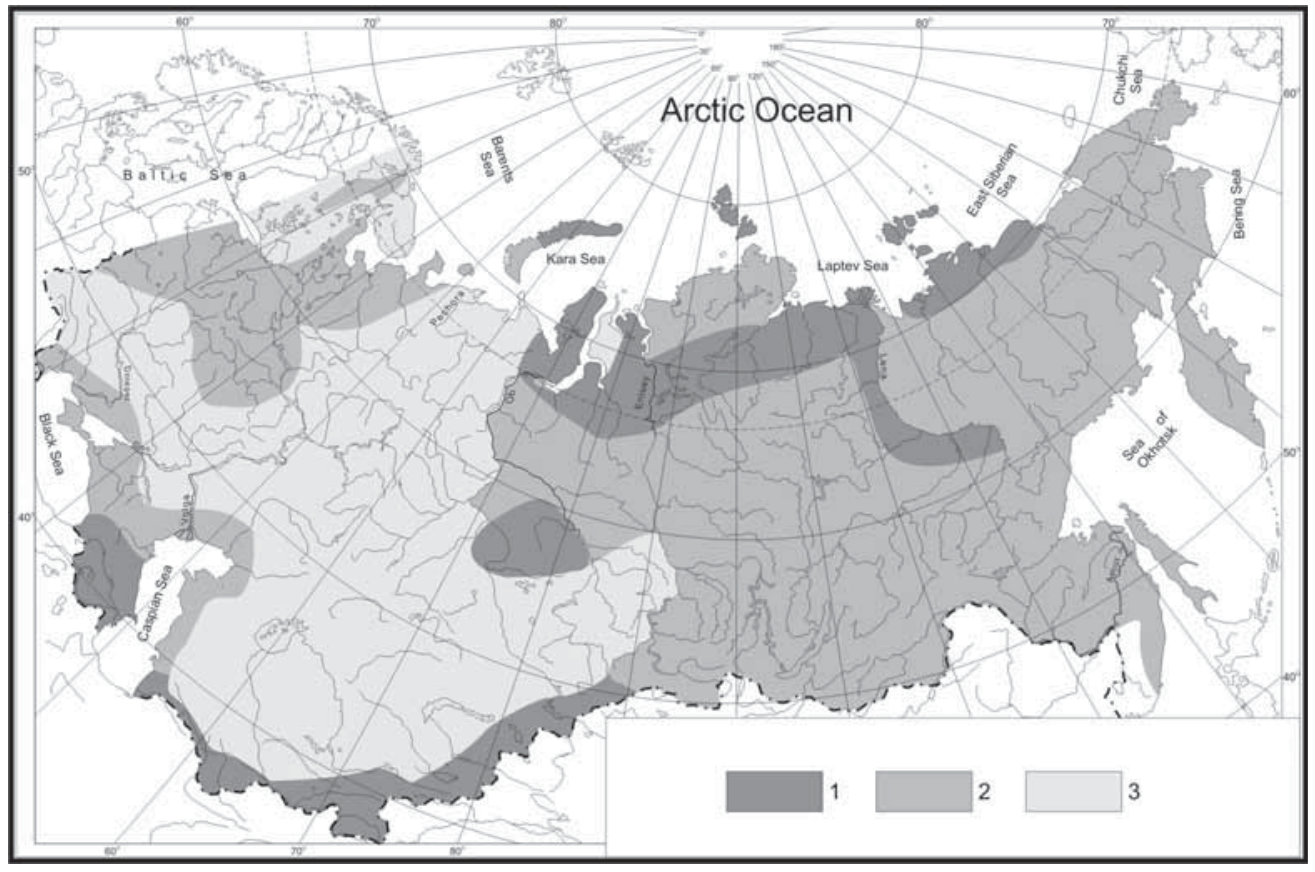

Figure 3. Degrees of geosystem destabilization under conditions of man-induced warming by the middle of the $21^{\text {st }}$ century.

1 - very high, 2 - high; 3 - moderate.

of focusing attention on the geosystems that likely pass from quasi-equilibrium state into non-equilibrium. Being temporarily unstable, they would become susceptible to any interference, and it is quite possible that resulting unfavourable changes may become irreversible. An assessment of possible destabilization of geosystems is given in Fig. 3.

Among potentially unstable regions, first to be mentioned are northern plains where decay of permafrost is expected being accompanied by solifluction, thermokarst, thermal erosion, etc. The risk of accelerated erosion, along with development of landslides, etc. is very high in the zone of arid and semiarid geosystems where some increase in precipitation is predictable. A hazardous situation may develop in the regions composed of highly erodible loess soils (the southern part of the East European Plain, the northern coasts of the Black Sea, and the North
Caucasian forelands). There is considerable risk of activation of dangerous processes in mountains. Melting of alpine glaciers and more abundant precipitation would result in more frequent avalanches and landslides (Caucasus) and mudflows (Pamir and Tien-Shan).

\section{REFERENCES}

Davidovich, N.V., Ananicheva, M.D. and Kononov, Yu.M. (2010), Glaciation, in Velichko, A.A. (ed.), Climates and landscapes of Northern Eurasia under conditions of global warming, GEOS Publishers, Moscow, pp. 142-157 [in Russian].

Dedkov, A.P. and Mozzherin, V.I. (1984), Erosion and solid runoff in the World, Kazan University Press, Kazan.

Frenzel, B., Pecsi, M. and Velichko, A.A., (eds). (1992), Atlas of paleoclimates and paleoenvi- 
ronments of the Northern Hemisphere (Late Pleistocene - Holocene), Geographical Research Institute, Budapest, Gustav Fisher Verlag, Stuttgart.

Kotlyakov, V.M., (ed.) (2006), Modern glaciation of Northern and Central Eurasia, Nauka Publishers, Moscow, [in Russian].

Kotlyakov, V.M., Grosswald, M.G., Durgerov, M.B. and Mazo, V.L. (1991), Response of glaciation to the forthcoming changes of climate, Izvestiya Akademii Nauk SSSR, Seriya Geographicheskaya, 5: 35-45 [in Russian].

Lurye, P.M., Panov, V.D. and Tkachenko, Yu.Yu. (2005), Kuban River: hydrographic regime, Gidrometeoizdat Publishers, St.-Petersburg, [in Russian].

Mokhov, I.I., Semenov, V.A. and Khon, V.U. (2002), Regional variations of hydrological regime in the 20th century and model-based estimates of their changes in the 21st century, in: Global climate changes and their consequences for Russia, Publisher: Regional social organization of scientists on the problems of applied geophysics, Moscow, pp. 310-333 [in Russian].

Parry, M.L., Canziani, O.F., Palutikof, J.P., van der Linden, P.J. and Hanson, C.E. (eds.) (2007), Climate Change 2007. Impacts, Adaptations and Vulnerability. Contribution of Working Group II to the Fourth Assessment Report of the Intergovernmental Panel on Climate Change, Cambridge University Press, Cambridge.

Semenov, S.M., (ed.) (2008), Appraisal report on changes of climate and their consequences on the territory of the Russian Federation, Vol. 2, Rosgidromet Publishing House, Moscow, [in Russian].

Starkel, L. (2002), Change in frequency of extreme events as the indicator of climatic change in the Holocene (in fluvial systems), Quaternary International, 91: 25-32.

Velichko, A.A. (1989), Evolutionary analysis of the contemporary landscape sphere of the earth and prognosis, Quaternary International, 2: 35-42.
Velichko, A.A. (1991), Global changes of climate and response of the landscape sphere, Izvestiya Akademii Nauk SSSR, Seriya Geographicheskaya, 5: 5-21 [in Russian].

Velichko, A.A. (1992), Zonal and macroregional changes in landscapes and environments resulting from the "greenhouse effect", Izvestiya Rossiyskoy Akademii Nauk, Seriya Geographicheskaya, 2: 89-102 [in Russian].

Velichko, A.A., (ed.) (2002), Dynamics of terrestrial landscape components and inner marine basins of Northern Eurasia during the last 130000 years, GEOS Publishers, Moscow, [in Russian].

Velichko, A.A., (ed.) (2009), Paleoclimates and paleoenvironments of extra-tropical regions of the Northern Hemisphere. Late Pleistocene Holocene, Moscow, GEOS Publishers, 120 p., 24 maps [in Russian].

Velichko, A.A., (ed.) (2010), Climates and landscapes of Northern Eurasia under conditions of global warming. Retrospective analysis and scenarios, GEOS Publishers, Moscow, [in Russian].

Velichko, A.A., Borisova, O.K., Gurtovaya, E.E. and Zelikson, E.M. (1991), Climatic rhythm of the last interglacial in Northern Eurasia, Quaternary International, 10-12: 191-219.

Velichko, A.A. and Lebedeva, I.M. (1974), Paleoglaciological reconstructions for the Eastern Pamir, Materials of Glaciological Studies, 23: 109-117 [in Russian].

Velichko, A.A., Starkel, L., (eds.) (1994), Paleogeographical basis of the modern landscapes. Results of Russian-Polish research, Nauka Publ., Moscow, [in Russian].

Zelikson, E.M., Borisova, O.K. and Velichko, A.A. (2010), Vegetation, in Velichko, A.A. (ed.), Climates and landscapes of Northern Eurasia under conditions of global warming. Retrospective analysis and scenarios, GEOS Publishers, Moscow, pp. 110-119 [in Russian].

Paper first received: April 2011

In final form: July 2011 
http://rcin.org.pl 


\section{INFORMATION FOR AUTHORS}

The editors of Geographia Polonica invite theoretical and empirical contributions to human as well as physical geography, in broad terms. Articles are expected to be original and not yet published elsewhere unless in languages other than English.

MANUSCRIPTS. Manuscripts, in the English language, should be submitted to the Editor of Geographia Polonica (Institute of Geography and Spatial Organization, Polish Academy of Sciences, Twarda 51/55, 00-818 Warszawa, Poland).

As all manuscripts will be reviewed, therefore, authors are kindly requested to provide two hard copies of the complete text (main text, abstract, references, tables, illustrations) and one copy delivered in an electronic form in MS Word.

The manuscripts should be arranged in the following order. First sheet: title, full name of author(s), affiliation, full postal adress, e-mail address . Second sheet: abstract of no more than 100 words, key words (3-10) at the end of the abstract. Subsequent sheets: the main text of about 20-25 pages (in A4 format). Then on separate sheets: acknowledgement (if desired), notes, references, tables, illustrations, captions to illustrations.

The main text may be organized in sections under appropriate headings without numerals.

SPACING. Manuscripts should be printed with 1,5 lines spacing without indents; for paragraphs enter a line space.

REFERENCES should be printed in alphabetical sequence at the end of the text. Examples:

Articles from journals:

Perroux, F. (1950), Economic space:Theory and applications, Quarterly Journal of Economics, 64: 89-104,

Kotarba, A. (1992), Denudacja mechaniczna Tatr Wysokich pod wpływem opadów ulewnych [Mechanic denudation in the High Tatra Mountains caused by downpours], Prace Geograficzne 195, Instytut Geografii i Przestrzennego Zagospodarowania (IGiPZ), PAN: 191-208.

Books:

Stren, R.,White, R. and Whitney, J. (1992), Sustainable cities, London, Jessica Kingsley Publishers.

Chapters from books:

Dematteis, G. (1996), Toward a unified metropolitan system in Europe: Core centrality versus network distributed centrality, in Pumain, D. and Saint-Julien, T. (eds.), Urban networks in Europe, INED, John Libbey, Paris, 19-28.

Theses:

Elfring, T. (1987), Service employment in advanced economies, Unpublished Ph.D. thesis, Rotterdam, Erasmus University, School of Management.

References should be indicated in the text by listing, in parenthesis, the author's name followed by the data of publication, e.g. (Kowalski 1995) or (Kowalski and Brown 1996) or (Kowalski et al. 1997) if there are more than two authors (Note: all the authors should be listed in the references).

FOOTNOTES and NOTES should be referred to by superscript letters.

ILLUSTRATIONS should be supplied in one of the following formats:

- photographs: JPG, TIFF, EPS or PSD,

-maps, figures and diagrams should be presented as vector files in AI (Adobe Illustrator) or one of the format mentioned above.

Please ensure that the resolution is not lower than $300 \mathrm{dpi}$ and the lines are a minimum of 0.3 points thick. Please also supply printouts of illustrations that are to be presented, in black and white or in colours, in relation to the required final appearance in print.

TABLES should be printed on separate sheets and numbered sequentially with Arabic numerals (e.g. Table 1). Each table should be provided with a clear descriptive caption at the top and informative column headings.

EQUATIONS and SYMBOLS used in mathematical formulae must be clearly explained. Axes on graphs should be described clearly. Units and abbreviations used by authors should conform to the International List.

MEASUREMENTS should be given in metric units.

ACCEPTED MANUSCRIPTS. After acceptance for publication, authors will receive page proofs for approval before publication. The revised manuscript should be returned promptly to the Editor.

Articles accepted for publication in Geographia Polonica are not honoured financially. Authors of accepted articles will receive one copy of the journal free of charge.

Authors are responsible for indicating copyright as well as permission from the copyright holder to reproduce any texts, tables or illustrations for which copyright exists. 


\section{CONTENTS}

An Appreciation to Professor Leszek M. Starkel

\section{TADEÁŠ CZUDEK}

Two different modes of the origin of Pleistocene pediments:

An example from the Central Moravian Carpathians, Czech Republic

\section{MAREK DEGÓRSKI, ALOJZY KOWALKOWSKI}

The use of SEM morphoscopy in researching the litho-pedogenetic environments evolution of Late Pleistocene and Holocene

\section{PIOTR GĘBICA}

Stratigraphy of alluvial fills and phases of the Holocene floods in the Lower Wisłok River valley, SE Poland

KLAUS HEINE, JÖRG VÖLKEL

Extreme floods around AD 1700 in the northern Namib Desert, Namibia, and in the Orange River catchment, South Africa - Were they forced by a decrease of solar irradiance during the Little Ice Age?

\section{MARIA ŁANCZONT, TERESA MADEYSKA}

Environmental changes recorded in some important peri-and meta-Carpathian Palaeolithic sites and their chronostratigraphy

\section{ANDREY PANIN, YULIA FUZEINA, INESSA KAREVSKAYA, ELENA SHEREMETSKAYA}

Mid-Holocene gullying indicating extreme hydroclimatic events in the centre of the Russian Plain

\section{ANTO RAUKAS}

Evolution of aeolian landscapes in north-eastern Estonia under environmental changes

\section{MILOŠ STANKOVIANSKY, PETER PIŠÚT}

Geomorphic response to the Little Ice Age in Slovakia

\section{KRYSTYNA TURKOWSKA, DANUTA DZIEDUSZYŃSKA}

Local evidence of landform evolution vs. global changes

- A case of Younger Dryas study in the upper Ner valley system, Central Poland

\section{JULIUSZ TWARDY}

Influence of man and climate changes on relief and geological structure transformation in central Poland since the Neolithic

ANDREY A. VELICHKO, IRINA I. SPASSKAYA

Approaches to assessment of relief-forming processes under conditions of global warming (with reference to Northern Eurasia within the boundaries of the former USSR 